\title{
Correspondence
}

http://dx.doi.org/10.11646/phytotaxa.222.2.11

\section{A new combination and new synonym in the Neotropical Heliotropiaceae}

\author{
JOSÉ IRANILDO MIRANDA DE MELO ${ }^{1 *} \&$ JOSÉ LUIS FERNÁNDEZ-ALONSO ${ }^{2}$ \\ ${ }^{1}$ Universidade Estadual da Paraíba, Centro de Ciências de Biológicas e da Saúde, Departamento de Biologia, Av. das Baraúnas, 351 \\ - Bairro Universitário, 58429-500, Campina Grande, Paraiba, Brazil; tournefort@gmail.com \\ ${ }^{2}$ Real Jardin Botánico de Madrid-CSIC, Consejo Superior de Investigaciones Científicas, Plaza de Murillo, 2 - 28014, Madrid, Spain; \\ jlfernandeza@rjb.csic.es \\ *Author for correspondence
}

\begin{abstract}
A new combination in Euploca and a new synonym in Tournefortia (Heliotropiaceae) from the Neotropics are proposed here. Heliotropium purdiei is combined under the genus Euploca and Tournefortia spicata is proposed as a synonym of T. romeroi.
\end{abstract}

Key words: Heliotropiaceae, nomenclature, Boraginaceae sensu lato

\section{Resumen}

Se propone aquí una nueva combinación en Euploca y un nuevo sinónimo en Tournefortia (Heliotropiaceae) del Neotropico. Heliotropium purdiei es combinada en el género Euploca y Tournefortia spicata es propuesta como sinónimo de T. romeroi.

\section{Introduction}

During a revision of Neotropical collections we encountered the type specimen of a species treated under Heliotropium Linnaeus (1753: 130) that showed morphological features of the genus Euploca Nuttall (1836: 189), as well as the type representing a species of Tournefortia Linnaeus (1753:140) originally circumscribed to another specific name.

Hilger \& Diane (2003) reestablished the genus Euploca based on molecular and morphological data to accommodate species of Heliotropium sect. Orthostachys R. Brown (1810: 493), Hilgeria Förther (1998: 132), and Schleidenia Endlicher (1839: 646). Euploca currently includes 53 names, but Diane (2003) observed that it comprises approximately 100 species distributed in tropical, subtropical, and temperate regions, with centers of diversity in Africa, Australia, and tropical America. This author considered Euploca a cosmopolitan genus, but Melo \& Semir (2010) pointed out that the majority of its species occur in South America and Mexico, where approximately 80 species can be found.

According to Hilger \& Diane (2003), the representatives Euploca are herbs, small shrubs, often as least basally decumbent; inflorescences ebracteate, bracteate, frondose or reduced to a solitary flower; anthers long protracted with pubescent apex, coherent apically, closing the corolla tube; fruit dry, separating into one-seeded maricarpids each with two pits on the abaxial side, rarely dry drupes with 4 one-seeded endocarpids, and embryo curved.

In this context, the presence of bracteate inflorescences, anthers apically coherent, fruits separating into four one-seeded mericarpids, and embryo curved in Heliotropium purdiei I.M.Johnst. (1928: 60), a Neotropical species of Heliotropiaceae native to Colombia and Venezuela (Miller 2015a), suggests its accommodation into Euploca. This work proposes the new combination of the above cited species of Heliotropium into the genus Euploca.

Regarding Tournefortia, we verified that one species, described for western Colombia as T. spicata J.S.Mill. (1989: 619), encompasses the morphological concepts of T. romeroi I.M.Johnst. (1956: 294), a species previously described for the above cited region. Thus, $T$. spicata is proposed here as a synonym of $T$. romeroi. The herbarium acronyms follow Thiers (2015). 


\section{Euploca purdiei (I.M.Johnst.) J.I.M. Melo \& Fern. Alonso, comb. nov.}

Basyonim: Heliotropium purdiei I.M.Johnst. (1928: 60). Type:-COLOMBIA. Magdalena: “Valle Dupar”, Santa Marta, July 1844, Purdie s.n. (holotype K!, isotype GH!).

2. Tournefortia romeroi I.M.Johnst. (1956: 294). Type:-COLOMBIA. Nariño: Km 86 Tumaco, El Diviso, 27 Julio 1952, R. Romero-Castañeda 3317 (holotype A!, isotype COL 50007!).

= Tournefortia spicata J.S. Mill., syn. nov. (1989: 619-622). Type:-COLOMBIA. Mpio. Tumaco, 80 Km from Tumaco along road to Pasto, in wet area of primary forest, near Orbignya palms and streams, "Guayacana", 19 July 1984, M. J. Balick, L. E. Forero P., S. R. King \& N. Hernández 1667 (holotype MO!, isotype MA 400047!).

Several species of Tournefortia sect. Tournefortia I.M.Johnst. (1930: 66) are encountered on moist Pacific-facing slopes in Colombia and Ecuador, among which is T. romeroi, which grows below $500 \mathrm{~m}$ a.s.l. in Nariño Department, Colombia (Johnston 1956, Miller 2015b). Other species were recently described there and are considered endemic to that region, including: T. spicata, from the Pacific plains near Nariño; T. restrepoae J.S.Mill., from mountain forests near La Planada, Nariño, at 1800 m (Miller 1989, 1995); and T. gigantifolia J.S.Mill., widespread throughout western Colombia and Peru (Miller 2000).

The species Tournefortia restrepoae and T. gigantifolia can be clearly distinguished from T. romeroi: the former due to its lax inflorescences with pedicellate flowers, and the latter due to its monocaulous habit, with very large grouped-leaves, with glabrescent blades punctuated on their upper surfaces. The known collections of T. spicata, however, are very similar to T. romeroi in terms of their sizes, indumentum, leaf features, inflorescences, and floral reproductive whorls. The slight differences in leaf morphologies, inflorescences, and flowers noted in the description of $T$. spicata are within the range of variability of T. romeroi. Accordingly, we consider T. spicata conspecific with the previously published $T$. romeroi.

\section{Acknowledgements}

J.I.M. Melo thanks CNPq (National Council of Scientific and Technologic Development) for the Productivity Research fellowship (PQ-2), and the Department of Biology, State University of Paraíba (UEPB) for permission for the travel to Madrid, Spain. A.L. Fernández-Alonso thanks the Spanish National Research Council (CSIC) for financing project CGL 2010-19747, which facilitated the study of the species discussed here.

\section{References}

Brown, R. (1810) Prodromus Florae Novae Hollandiae et Insulae Van-Diemen, etc. Nuremberg: L. Schrag.

Diane, N. (2003) Systematic analysis of the Heliotropiaceae based on molecular and morphological-anatomical data. Thesis (Ph.D. in Biology), Freie Universität, Berlin, 34+124 pp.

Endlicher, S.F.L. (1839) Genera plantarum secundum ordines naturales disposita. Fr. Beck, Universitatis Bibliopolam, Wien, 1483 pp.

Förther, H. (1998) Die infragenerische Gliederung der Gattung Heliotropium L. und ihre Stellung innerhalb der subfam. Heliotropioideae (Schrad.) Arn. (Boraginaceae). Sendtnera 5: 35-241.

Hilger, H.H. \& Diane, N. (2003) A systematic analysis of Heliotropiaceae (Boraginales) based on trnL and ITS1 sequence data. Botanische Jahrbücher für Systematik, Pflanzengeschichte und Pflanzengeographie 125: 19-51.

http://dx.doi.org/10.1127/0006-8152/2003/0125-0019

Johnston, I.M. (1928) Studies in Boraginaceae 7: The South American species of Heliotropium. Contributions from the Gray Herbarium of Harvard University 81: 3-73.

Johnston, I.M. (1930) Studies in Boraginaceae 8: Observations on the species of Cordia and Tournefortia known from Brazil, Paraguay, Uruguay and Argentina. Contributions from the Gray Herbarium of Harvard University 82: 3-89.

Johnston, I.M. (1956) Studies in the Boraginaceae XXXVII. New or otherwise interesting species from America and Asia. Journal of the Arnold Arboretum 37: 288-306.

Linnaeus, C. (1753) Species Plantarum 1. Impensis Laurentii Salvii, Stockholm, 560 pp. 
Melo, J.I.M. \& Semir, J. (2010) Taxonomia do gênero Euploca Nutt. (Heliotropiaceae) no Brasil. Acta Botanica Brasilica 24: $111-132$. http://dx.doi.org/10.1590/S0102-33062010000100012

Miller, J.S. (1989) Two new species of Tournefortia (Boraginaceae) from Colombia. Annals of the Missouri Botanical Garden 76: 619622. http://dx.doi.org/10.2307/2399508

Miller, J.S. (1995) A new species of Tournefortia (Boraginaceae) from La Planada, Colombia. Novon 5: 188-189. http://dx.doi.org/10.2307/3392244

Miller, J.S. (2000) New Boraginaceae from Tropical America 3: A New Tournefortia from Ecuador and Colombia. Novon 10: 48-52. http://dx.doi.org/10.2307/3393184

Miller, J.S. (2015a) Heliotropium purdiei I.M.Johnst. In: Bernal, R., Gradstein, S.R. \& Celis, M. (Eds.) Catálogo de plantas y líquenes de Colombia. Instituto de Ciencias Naturales, Universidad Nacional de Colombia, Bogotá. Available from:http://catalogoplantascolombia. unal.edu.co/ (accessed 16 June 2015)

Miller, J.S. (2015b) Tournefortia. In: Bernal, R., Gradstein, S.R. \& Celis, M. (Eds.) Catálogo de plantas y líquenes de Colombia. Instituto de Ciencias Naturales, Universidad Nacional de Colombia, Bogotá. Available from: http://catalogoplantascolombia.unal.edu.co/ (accessed 17 June 2015)

Nuttall, T. (1836) Collections towards a flora of the territory of Arkansas. Transactions of the American Philosophical Society 5: 137203.

Thiers, B. (2015) [continuously updated] Index herbariorum: a global directory of public herbaria and associated staff. New York Botanical Garden's Virtual Herbarium. Available from: http://sweetgum.nybg.org/ih/ (accessed 10 June 2015) 